\title{
On tone and segmental processes in Akan phrasal words:
}

\author{
A prosodic account
}

\author{
Charles Ofosu Marfo (Hong Kong)
}

\begin{abstract}
Based on where and how phonological rules apply, studies in Lexical Phonology (Mohanan 1986; Kiparsky 1985; Pulleyblank 1986; etc.) distinguish between two levels in the phonology; namely, lexical and post-lexical. At the post-lexical level, the various phonological rules normally require particular domains, without which they fail to apply. The question that follows is where and how we define these domains. Considering Akan NounNoun and Noun-Adjective phrasal word (compound) constructions in prosodic phonology (Selkirk 1986, Nespor and Vogel 1986 and Hayes 1989; etc.), this paper touches on some aspects of the prosody-syntax interface on the idea that the domain of a post-lexical rule is drawn from the prosodic component, an intermediate phase of interface analysis. The rules that come to bear are tonal (i.e. H-Deletion, H-Insertion and Boundary assimilation) and segmental (i.e. Prefix deletion and Diphthong simplification) ones that apply on the dictates of particular prosodic domain attainment. Thus, this paper argues that the syntactic structure influences these phonological rules, but indirectly through the prosodic structure (Inkelas 1989). Finally, the paper claims that with the prosodic domains occurrences are better defined and accounted for.
\end{abstract}

\section{Introduction}

Studies in lexical phonology (Kiparsky 1985; Mohanan 1986; Pulleyblank 1986; etc) underscore the idea that although many phonological rules apply lexically, some others could be defined in application beyond the level of phonological word. These rules are referred to as post-lexical or 'truly' phrasal rules (Hayes 1990, etc.). The existence of these phrasal phonological rules has stimulated a great deal of research in the study of phonology-syntax interface, particularly the component of grammar within which domains of phrasal rules application should be identified. Hence, attention has been given to the mapping between the syntactic constituent structure and that of the phonology (Kaisse 1985; Odden 1987; Selkirk 1981; Truckenbrodt 1999; Seidl 2001; etc.).

Through the Indirect Reference Hypothesis (Inkelas 1989, etc.), which basically rejects direct syntax involvement in phonological rule analyse, this paper suggests that phrasal rules require more than only some specific syntactic information or domains delineated in the syntactic constituent structure to apply. Rather than being entirely syntax-dependent, phrasal rules 
require the emergence of unique phonological domains to be triggered. Following Selkirk (1981; 1984; etc.), Nespor and Vogel (1982 \& 1986) among others, we suggest that these domains are the prosodic ones constituting the strictly layered prosodic structure. ${ }^{1}$ The position of this paper, therefore, is a well-known one. That is, the phrasal phonological rules only apply with properties of prosodic domains, and the syntactic constituent structure (along with other grammatical information) only constitutes the primary input base on which the domains of the prosodic structure are defined. In Akan, ${ }^{2}$ some of the phrasal rules occur.

Two NP-internal constructions in Akan are discussed along with phrasal rules that are triggered in their construction in this paper. These are Noun-Noun and Noun-Adjective (respectively referred to as $\mathrm{N}-\mathrm{N}$ and $\mathrm{N}-\mathrm{Adj}$, hereafter) compounds or phrasal words. The associated occurring phrasal rules are $\mathrm{H}$-Deletion, Prefix deletion, Diphthong simplification, H-Insertion and Boundary assimilation. This paper explains that in the two constructions both constituents may either parse into one primary prosodic phrase or separately from each other depending on the tonal structure of the first constituent (i.e. the head) or morphophonemic status of the second constituent (i.e. the complement). We realize, therefore, that the syntactic constituent structure alone cannot give a complete definition of rule domains, but instead rule domains are better defined in terms of prosodic considerations.

The paper is organized as follows: We look at Akan N-N and N-Adj compounds construction and the phonological processes that accompany their construction in section 2 . In section 3 , we determine the particular prosodic domain (with its properties) and other conditions that sensitize the phrasal processes. The determination of the prosodic domain will underscore the relevance of the prosodic structure, and highlight the mapping between phonology and syntax in the course of discussion. This will also underscore the lack of perfect isomorphy between syntactic units and domains of the prosodic structure. Section 4 also looks at the manifestation of the morphophonemic property of number (specifically, the plural), its effect in the prosodic domain determination and subsequent influence in the occurring processes in the compound constructions. We then conclude in section 5 with the reiteration that there would be irregularities in accounting for the occurring phonological rules if categories of the syntactic constituent structure directly constitute domains of the rules.

\footnotetext{
${ }^{1}$ The prosodic structure, a subsystem of the phonological structure, is constituted by different units/domains of rule analysis. Linguists differ on the number of these levels. In a descending order (that is from the largest to the smallest unit) we adopt Nespor and Vogel's (1986: 11) general proposal of the following seven prosodic units/levels: Phonological utterance $(U)$, Intonational phrase $(I)$, Phonological phrase $(\phi)$, Clitic group $(C)$, Phonological word $(\omega)$, Foot $(\Sigma)$ and Syllable $(\sigma)$.

${ }^{2}$ Akan is a member of the Kwa subgroup of the Niger-Congo language family and mainly spoken in Ghana. Akan is also commonly referred to as Twi and comprises three main dialects; namely, Asante, Fante, and Akuapim. This paper focuses on Asante-Twi, although throughout the analyses we will be using the name Akan. This is in order to preclude tonal and segmental differences among the dialects that are capable of complicating issues for us to deal with. All data provided in the language are, therefore, from Asante-Twi and are taken from Dolphyne (1988), a very detailed descriptive work, and Marfo (2001).
} 


\section{$2 \quad$ NP-internal constructions and processes}

Compounding is one way by which Akan increases its stock of vocabulary, particularly nouns. It is done through the association of words from the same part of speech or different parts of speech. In this paper, we focus on N-N and N-Adj compounds - i.e. connected speeches of lexical units within the noun phrase (NP). In the construction of these NP-internal compounds, some tonal and segmental phonological processes are triggered. Based on these processes, compounding constitutes one of the areas where the interface between syntax and phonology is manifested in Akan. Beside a look into N-N and N-Adj compounding in Akan, our goal in this section is to identify and explain these phonological processes or rules.

A compound is generally discussed in the literature as a morphosyntactic process (Lieber 1980, etc.). Traditionally, a compound is described as a 'new' word made out of other existing and independent words. Anderson (1985: 40), for example, describes a compound as 'word formation based on the combination of two or more members of (potentially) open lexical classes'. In other words, a compound is a quasi-syntactic unit or structure. ${ }^{3}$ Although the Akan situation fits well into Anderson's definition, we suggest a more general term for Akan, namely, phrasal word. This is in order to stay away from the controversy surrounding the definition of a compound. We define a phrasal word in this paper as a (syntactic) word, which is composed of two or more lexical or free constituents. In the following, we explore the phonology-syntax interface with respect to tonal and segmental processes.

\section{$2.1 \quad \mathrm{~N}-\mathrm{N}$ and $\mathrm{N}$-Adj phrasal words}

In N-N phrasal word constructions in Akan, the first noun (N1) modifies the second noun (N2), as Dolphyne (1988) rightly points out. N1, then, behaves like an adjective. Contrary to the N-N situation, in Akan, an adjective comes after the noun it modifies. In a phrasal word involving a noun and an adjective, this noun-adjective word order is reflected in many of them. We exemplify N-N and N-Adj phrasal words in (1a \& b) respectively.

(1) Phrasal words

a. N1-N2 : òdwái, òníní 'sheep, a male' » òdwààníní 'a ram'

b. N1-Adj : àsém, húnú 'a story, useless' » àsèmhhúnú 'nonsense'

Some phrasal words have been lexicalized. As can be observed in (1), when a phrasal word is lexicalized, the individual meanings of the constituents involved may not be explicitly evident in the meaning of the derived word. In addition, the modification effect may be overshadowed, but not totally lost (perhaps, due to the compositionality principle, which requires some semantic realization of lexical items constituting a phrasal word). These two characteristics of a lexicalized phrasal word constitute the main difference between it and a

\footnotetext{
${ }^{3}$ See Lieber (1980), Selkirk (1982), Anderson (1985), and many others for detail discussions on compound words and compound formation.
} 
non-lexicalized phrasal word, as those in (2). ${ }^{4}$ However, we classify both of them as one syntactic unit and as phrasal words.

(2) Non-lexicalized phrasal words

\begin{tabular}{|c|c|c|c|}
\hline$\underline{\mathrm{N}-\mathrm{N}}$ & ònùá, òdó & 'sibling, love' & » ònùàdó 'brotherly love' \\
\hline \multirow{3}{*}{$\underline{N \text {-Adj }}$} & kr̀̀̀nóó, àdéć & 'thievery, a thing' & » kr̀̀̀nòdéć 'stolen good' \\
\hline & غ̀kwáí, kèséć & 'a way, big' & » غ̀kwài ké!séć 'big way' \\
\hline & dùá, téńtéń & 'a tree, tall' & » dùà téńtéń 'black cola' \\
\hline
\end{tabular}

\subsection{Basic rules of construction:}

\subsubsection{H-Deletion}

A basic tonal alteration consistently occurs in the construction of $\mathrm{N}-\mathrm{N}$ and N-Adj phrasal words. Specifically, in the construction an N1 gets rid of its stem non-low tones (i.e. $\mathrm{H}$ and !H) and pronounce low (L) by default before the complement (i.e. N2 or Adj). Schematized in (3), let us refer to this tonal alteration as the H-Deletion rule. The realization of the rule in $\mathrm{N}$ $\mathrm{N}$ and $\mathrm{N}$-Adj phrasal words is also exemplified in (4). ${ }^{5}$

(3) The H-Deletion rule

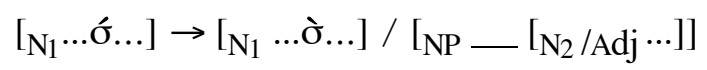

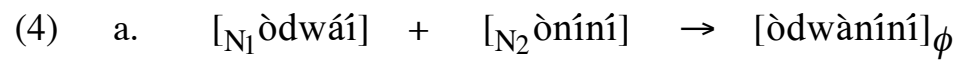
'a sheep' 'a male' 'a ram'

b. $\left[{ }_{\mathrm{N}_{1}}\right.$ àséḿ́ $]+\left[_{\mathrm{N}_{2}}\right.$ húnú $] \rightarrow$ [àsèmhúnú $]_{\phi}$ 'a story' 'useless' 'nonsense'

As we can see in both nouns in (4a), almost all Akan nouns have a lexical L toned prefix in the singular form. In the application of H-Deletion, there is a tendency to account for the $\mathrm{L}$ tone that prevails in $\mathrm{N} 1$ as a regressive spread of this lexical $\mathrm{L}$ tone of the deleted prefix of N2. ${ }^{7}$ Although such an assumption seems reasonable, we note that it does not take all cases into account. Observe in (4b) that $\mathrm{N} 1$ is also pronounced $\mathrm{L}$ by default, although the adjective is without a prefix, let alone an L-toned one. In Akan, adjectives are without a prefix. Again, even with the N-N phrasal words there are cases where no prefix is found in $\mathrm{N} 2$, but $\mathrm{H}$ -

\footnotetext{
${ }^{4}$ With the non-lexicalized phrasal words, the semantic content of the individual constituents must be equally represented in the meaning, hence their non-lexicalization.

5 The H-deletion rule would better be called 'Non-Low-Deletion' to include the downstep high, but for convenience and standard terminology usage, I adopt the term 'H-deletion' and note that with its application no distinction is made between an $\mathrm{H}$ tone and a downstep $\mathrm{H}$ tone.

${ }^{6} \mathrm{I}$ draw attention to the fact that H-Deletion on N1 is more or less optional in the noun-adjective sequence, except in the lexicalized cases. This optional rule, however, sets apart a true phrasal word from an ordinary noun-adjective word order (where H-Deletion does not apply), although in the non-lexicalized cases they may be semantically non-distinctive.

${ }^{7}$ An N2 prefix is always deleted in the phrasal word construction. This deletion is looked at again in the discussion in section 2.2.2 with diphthong simplification.
} 
Deletion and the subsequent realization of default L tone in $\mathrm{N} 1$ still take place, as shown in (5).

(5) N2 with no (L-toned) prefix

\begin{tabular}{|c|c|c|c|c|}
\hline $\begin{array}{l}\text { a. [ [ }{ }_{\mathrm{N}_{1}} \text { sìká] } \\
\text { 'money' }\end{array}$ & + & $\begin{array}{l}\text { [ }{ }_{\mathrm{N}_{2}} \text { bótó] } \\
\text { 'a sack' }\end{array}$ & $\rightarrow$ & $\begin{array}{l}\text { [sikà bótó }]_{\phi} \\
\text { 'money bag/pocket' }\end{array}$ \\
\hline $\begin{array}{l}\left.\text { b. }{ }_{\mathrm{N}_{1}} \text { àsćḿ́ }\right]_{\omega} \\
\text { 'a story' }\end{array}$ & + & $\begin{array}{l}{\left[_{\mathrm{N}_{2}} \text { sé!réé }\right]_{\omega}} \\
\text { 'laughter' }\end{array}$ & $\rightarrow$ & $\begin{array}{l}\text { [àsèm̀̀ sé!réé] } \phi \\
\text { 'humor' }\end{array}$ \\
\hline
\end{tabular}

Based on the realization of $\mathrm{L}$ tone on N1s before adjectives and non-prefixed N2s, we affirm our earlier suggestion that with the application of H-Deletion, N1 is just pronounced low (L) by default. In fact, we will observe in section 2.3.1 that this L tone is actually a spread of an initial L tone in N1 in N-N phrasal words and an absolute default one in N-Adj phrasal words. In N-N and N-Adj phrasal words presented in (6) and (7) respectively, therefore, we show that $\mathrm{H}$-Deletion consistently applies irrespective of the syllabic or segmental representation of the constituents involved. Subsequently, we observe the realization of default L tone on N1s.

(6) N-N phrasal words

$\begin{array}{lll}\text { ǹyàmé, àsém } & \text { 'a god, a story' } & \text { » ǹyàmèsém 'the scriptures' } \\ \text { ǹnùá, èdáí } & \text { 'woods, a house' } & \text { » ǹnùàdáí 'wooden house' } \\ \text { àbó!sóm, èfié } & \text { 'idols, house' } & \text { »àbòsòmfié 'shrine' } \\ \text { àbó!fóó, c̀dái } & \text { 'messengers, house' } & \text { »àbòfòdáí 'guest house' }\end{array}$

(7) N-Adj phrasal words

$\begin{array}{lll}\text { ká!sá, téntéń } & \text { 'a talk, tall' } & \text { »kàsàténtéń 'a talkative' } \\ \text { siké, kòkòó } & \text { 'money, red' } & \text { »sikàkókòó 'gold' } \\ \text { dàdéć, kétéwá } & \text { 'metal, small' } & \text { »dàdè(kété)wá 'a nail' } \\ \text { èkwái, kèséć } & \text { 'way, big' } & \text { » c̀kwàà ké!séć 'big way' }\end{array}$

\subsubsection{Prefix deletion and Diphthong simplification}

Back to the data given so far, some of which have been repeated in (8) and (9) below, two other occurrences prevail within the resulting phrasal words. These are with regards to the kind of vowel sequence that is allowed at the word boundary of the two constituents involved in the phrasal word. Specifically, we realize that in a N-N phrasal word construction a prefix in N2 is deleted. ${ }^{8}$ We refer to this segmental occurrence as 'N2-prefix deletion' (henceforth, Pfx-Deletion). However, since it is straightforward we will not delve very much into it. In addition to Pfx-Deletion, we also observe in the data in (8) and (9) that a final diphthong in $\mathrm{N} 1$ is simplified in a phrasal word.

\footnotetext{
${ }^{8}$ Note that adjectives do not have prefixes, so prefix deletion only occurs in N-N phrasal words. Let us also note that, where the $\mathrm{N} 2$ prefix is a syllabic nasal it stays put in the phrasal word, as in (8d), for example.
} 
(8) Diphthong simplification in N-Ns
a. kòtéé, bótó
'penis, a sack'
» kòtèbótó 'uncircumcised'
b. àsó!fóó, èfié
'pastors, a house'
» àsòfòfíé 'a mission house'
c. òdwái, òníní
'sheep, a male'
» òdwààníní 'a ram'
d. ǹkwáí, ǹwó
'soup, oil'
e. ònùá, òdó
'sibling, love'
» ǹkwààǹwó 'a kind of oil'
» ònùàdó 'brotherly love'
f. ǹnùá, èdái
'woods, a house'
» ǹnùàdáí 'a wooden house'

(9) Diphthong simplification in N-Adjs
a. dàdéé, kétéwá 'metal, small'
» dàdè(kété)wá 'a nail'
b. àfidié, mónó 'machine, new'
» àfiđi mónó 'new machine'
c. ذ̀táí, húnú
'hatred, useless'
» òtàà húnú 'baseless hatred'
d. ̇̀kwáí, kèséé 'way, big'
» èkwàà ké!séé 'big way'

As proposed in (9) below, let us refer to this segmental word boundary occurrence in phrasal words as 'diphthong simplification' (henceforth, DiphSimple).

(10) Diphthong simplification

$$
\left[\mathrm{N}_{1} \ldots x y_{\text {Diph }}\right]_{w} \rightarrow\left[{ }_{\mathrm{N}_{1}} \ldots x / x x\right]_{W} /\left[\ldots\left[{ }_{\mathrm{N}_{2}} \ldots\right]_{w}\right]_{\text {phrasal word }}
$$

The proposal in (10) explains that DiphSimple is realized either through a simple shortening of the diphthong or a lengthening of one of the vowel in the diphthong. In the case of shortening the second of the two vowels is simply elided, as in ( $8 a \& b)$ and $(9 a \& b)$. On the contrary, with lengthening, the second of the two vowels is elided and the first is subsequently lengthened, as also shown in ( $8 \mathrm{c} \& \mathrm{~d})$ and $(9 \mathrm{c} \& \mathrm{~d})$. An occurring diphthong in $\mathrm{N} 1$ is, however, maintained where the final vowel of it is $/ a /$, as in $(8 \mathrm{e} \& \mathrm{f})$.

\subsubsection{H-Insertion in $\mathrm{N}$-Adj phrasal words}

In N-Adj phrasal words, an additional tonal rule prevails on the adjective. Specifically, the stem-initial syllable of the adjective resurfaces as $\mathrm{H}$ toned in the construction. I refer to this tonal phenomenon as H-Insertion, as put forward in (11). H-Insertion is explicit where the syllable absorbing the inserted $\mathrm{H}$ is lexically $\mathrm{L}$.

\section{H-Insertion}

$$
\left[{ }_{\text {Adj }} \grave{\sigma}_{1} \ldots \sigma_{n}\right] \rightarrow\left[\left[_{\text {Adj }} \sigma_{1} \ldots \sigma_{n}\right] /\left[{ }_{N P}\left[N_{1}\right]\right.\right.
$$

In the application of $\mathrm{H}$-Insertion, the lexical $\mathrm{L}$ tone of the adjective is either displaced or delinked. A displacement or delinking of the lexical $\mathrm{L}$ tone is dependent on whether the succeeding syllable is $\mathrm{H}$-toned or also $\mathrm{L}$ (as the initial one) respectively. If the following syllable is $\mathrm{H}$-toned, its pitch level is reduced by the impact of the displaced $\mathrm{L}$ tone, resulting in a downstepped $\mathrm{H}$. This is structured and illustrated in (12a) and (12b) respectively. 
(12a)

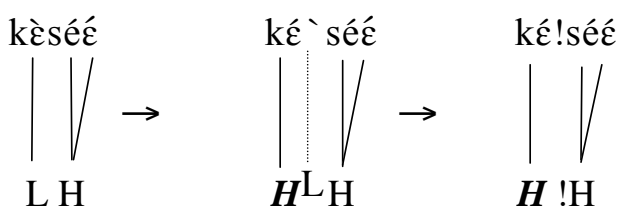

(12b) $\mathrm{H}$-Insertion in stem-initial $\mathrm{L}$ and succeeding $\mathrm{H}$ adjectives

$\begin{array}{llll}\text { dàdéé, kèséé } & \text { 'metal, big' } & \text { »dàdè ké!séé } & \text { 'big metal' } \\ \text { sìká, kèséć } & \text { 'money, big' } & \text { »sikà ké!séé } & \text { 'big money' } \\ \text { bìsé, tùǹtúm } & \text { 'cola, black' } & \text { »bìsè túń!túm } & \text { 'black cola' } \\ \text { ǹtòmá, tùǹtúm } & \text { 'cloth, black' } & \text { » ǹtòmà túń!túm } & \text { 'black cloth' }\end{array}$

On the other hand, where the succeeding syllable is also L, in consonance with Obligatory Contour Principle (OCP: Leben 1973; Odden 1986; Antilla \& Bodomo 2000; etc.), we assume that no $\mathrm{L}$ tone has been set afloat. That is, the initial syllable shared in a common $\mathrm{L}$ tone, and so has only been delinked from the tier of that common L tone. Structured in (13a), we also illustrate the detachment from a lexical tone tier in some phrasal words in (13b).

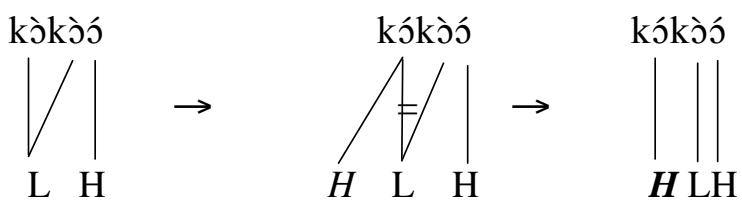

(13b) $\mathrm{H}$-Insertion in stem-initial $\mathrm{L}$ and succeeding $\mathrm{L}$ adjectives

\begin{tabular}{|c|c|c|c|}
\hline ká, kòkòó & 'money, red' & » sìkà kókòó & 'gold' \\
\hline \{, kòkòó & 'cloth, red' & » ǹtòmà kókòá & 'red cloth' \\
\hline & 'soup, sweet' & » ǹkwàà dé(èdé) & 'sweet soup' \\
\hline & 'song, sweet' & » ǹnwòm̀ dé( & weet song' \\
\hline
\end{tabular}

$\mathrm{H}$-Insertion also applies in an adjective with $\mathrm{H}$-initial syllable. Contrary to its obvious effect on an L-initial syllable, however, we assume that the inserted $\mathrm{H}$ covertly docks on the syllable and merges with its lexical H. This analysis is in line with the universal grammar (UG) convention of merging two identical tones, which are assigned to a single bearing unit (Goldsmith 1976, etc.). The structure in (14a) illustrates the merger that has taken place on the adjectives in (14b).

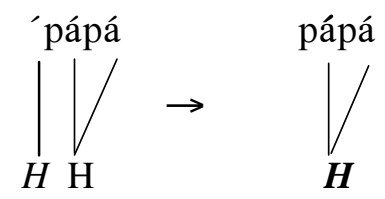

(14b) H-Insertion in H-initial adjectives

$\begin{array}{llll}\text { ǹtòmá, pápá } & \text { 'cloth, good' } & \text { » ǹtòmà pá(pá) } & \text { 'good cloth' } \\ \text { bìsé, nwónó } & \text { 'cola, bitter' } & \text { » bìsè nwónó } & \text { 'bitter cola' } \\ \text { sèmí!ná, fítáá } & \text { 'a soap, white' } & \text { »sèmìnà fítáá } & \text { 'white soap' } \\ \text { àfidié mónó } & \text { 'machine, new' } » \text { àfidi mónó } & \text { 'new machine' }\end{array}$


With H-Insertion, an 'L][H' word boundary polarity is always created between the noun and the adjective if the $\mathrm{H}$ tones of the noun delete. Although $\mathrm{H}$-Insertion essentially applies along with H-Deletion, we note that it is not tied to H-Deletion because, as shown in (15), in an ordinary $\mathrm{N}$-then-Adj order where H-Deletion does not apply on the noun H-Insertion still applies in the adjective. The suggestion, then, is that $\mathrm{H}$-Insertion is an independent rule.

(15) H-Insertion in ordinary N-Adj order

\begin{tabular}{|c|c|c|}
\hline iká, kòkòó & 'money, red' & » sìká kókòó \\
\hline i. dèc̀ & 'soup, sweet' & » ǹkwáí déčdé 'tasty soup' \\
\hline & 'way, big' & » Èkwáí ké!séć 'big way' \\
\hline & 'cola, black' & » bìsé túń!túm 'black cola' \\
\hline
\end{tabular}

\section{Domain of phrasal words and associated rules}

At a glance, it is obvious that the syntactic phrase of NP constitutes the domain of the phrasal words construction and the rules that come along with them. However, following our earlier observation that syntactic involvement in phonological rules analyses is only remote, ${ }^{9}$ in the following, I contend that a particular prosodic phrase/domain of the prosodic structure, the phonological phrase (indicated as $\phi$ ), is instead the required domain. In addition, it is properties of the $\phi$ that the rules we have observed, particularly H-Deletion, see to apply.

The $\phi$-domain I define for Akan is, to a large extent, in consonance with the relation-based mapping theory (Nespor and Vogel 1986; Hayes 1989; etc.), which relies very much on heads of maximal projections. ${ }^{10}$ Generally, constituents under a maximal projection of a lexical head (i.e. $X P$ of $X$ ) constitute one $\phi$ in Akan. However, based on the fact that other grammatical information (such as lexical/non-lexical status of a word, tonal prominence, number, syllable structure etc.) may also contribute to prosodic phrasing (Hayes 1989; Frascarelli 2000; etc.) I propose the following $\phi$ construction scheme/rule in (16) for Akan. With the consideration of other grammatical facts, in a sense, this scheme is determined with the rules they are to explain in mind.

\section{(16) Phonological phrase ( $\phi)$ formation scheme}

a. In an IP, lexical constituent(s) in the specifier constitutes one phonological phrase whiles the head phrases with its complement (i.e. $\left[_{\mathrm{IP}} \mathrm{NP}\left[{ }_{\mathrm{VP}} \mathrm{V} \mathrm{NP}\right]\right]$ is mapped as $[\mathrm{NP}]_{\phi}[\mathrm{V} \mathrm{NP}]_{\phi}$ ).

b. Within the basic phonological phrases:

i. A tonally emphasized lexical head of a branching NP primarily phrases alone (emphasis is indicated by lexical tones maintenance);

ii. A pluralized NP complement also phrases separately.

\footnotetext{
${ }^{9}$ Recall that the Indirect Reference Hypothesis (Inkelas 1989, etc.) explains the remoteness of the syntactic structure as only an input base of the prosodic structure.

${ }^{10}$ There are two options of the relation-based mapping theory, that is either a) a head phrases with its complement or b) phrases separately from its complement. Using the theory as a kind of language parameter, we assume that no one language can have both of the options. So that, a language either adopts option (a) or (b) in phrasal rules analyses.
} 
It is obvious from the $\phi$ scheme in (16) that there cannot always be a one-to-one correspondence between a syntactic category and a particular domain in the prosodic structure. It will become evident that phrasal phonological rules are conveniently explained with the prosodic structure. If syntactic categories directly represent domains of phrasal rules, particularly those under discussions in this paper, the rules may not be adequately and wholly accounted for.

I suggest that a phrasal word is attained where constituents within an NP (i.e. N-N or N-Adj) could also be mapped into one $\phi$. Considering the Strict Layer Hypothesis (SLH: Selkirk 1981, 1984, 1986 etc.), which requires that each prosodic domain contains and only contains instances of the immediate smaller or lower domain, each of the constituents in the NPmapped $\phi$ is immediately a phonological word $(\omega),{ }^{11}$ as shown in $(17 \mathrm{a} \& \mathrm{~b})$ for $\mathrm{N}-\mathrm{N}$ and $\mathrm{N}$ Adj phrasal words respectively.

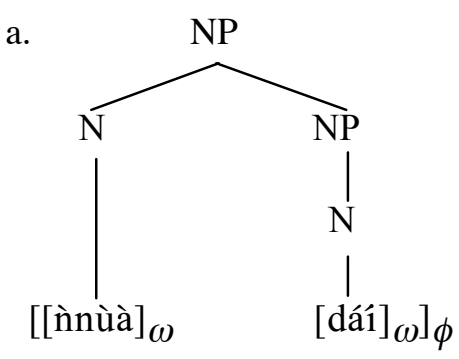

'Wooden-house'

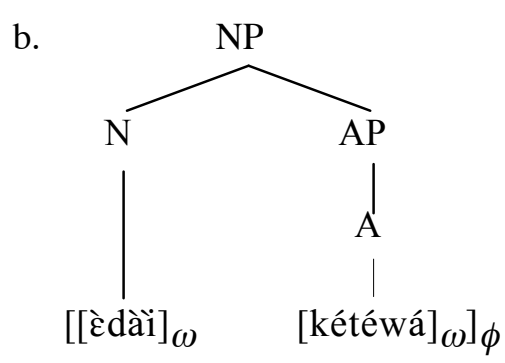

'Small house'

We also propose that our basic tonal rule on N1, H-Deletion, only applies within a primary $\phi$. Thus, where NP is not immediately mapped into one primary $\phi \mathrm{H}$-Deletion fails to apply. Nonetheless, as we will see in 3.3 , unless N2 (i.e. the complement) immediately phrases separately, we will still derive the phrasal word through $\phi$-rephrasing.

\subsection{N1 tonal structure and H-Deletion}

We have observed that H-Deletion consistently applies in phrasal words, irrespective of the syllabic or segmental representation of the constituents involved. However, an observation of a few other N-N phrasal words (compared with those we have seen so far) reveals that $\mathrm{H}$ Deletion is conditioned by the tonal structure/pattern of N1. The tonal structure of NI must follow a particular trend to be susceptible to H-Deletion, that is an initial-L and a final-H. Based on the importance of this tonal structure, I suggest that there is an active tonal condition in place, without whose satisfaction H-Deletion fails to apply. Stated in (18), let us refer to it as 'Word-Edge (ò...ó)':

(18) Word-Edge (ò...ó)

$\mathrm{H}$ tones of $\mathrm{N} 1$ must delete where the initial and final tones of it are $\mathrm{L}$ and $\mathrm{H}$ respectively in N-N phrasal words. 
As stated, Word-Edge requires an initial L tone on N1 (as the default L), which will takeover following the application of $\mathrm{H}$-Deletion by spreading through $\mathrm{N} 1$. Without this initial L tone, $\mathrm{H}$-Deletion becomes inapplicable. As can be seen in (19), therefore, H-Deletion fails in N1s of (19a, b \& c) because of the lack of initial $L$ tone representation in them.

(19) Non-application of H-Deletion
a. lóri, èkwái
'lorry, a way'
» lórìkwái 'a street'
b. ádàsà, m̀̀má
'mankind, children'
» ádàsàmmmá 'mankind'
c. táyà, àkóré
'catapult, a branch'
» táyà kóré '... for catapult'
d. kòóbi, ǹkwái
'salted-fish, soup'
» kòóbìnkwáí 'fish soup'
e. òwúrà, kwà:kú 'lord, $\mathrm{PN}^{\prime}$
» òwúrà(kwà:)kú 'a PN'

Observe also in (19d \& e) that, even where there is an initial L tone, since Word-Edge also prohibits a final L tone on N1, H-Deletion still fails to apply. It rather requires a final $\mathrm{H}$ tone. This part of Word-Edge could be reasoned in two ways. Firstly, considering the fact that $\mathrm{H}$ Deletion proceeds from the right-edge of $\mathrm{N} 1$ to its left and that only $\mathrm{H}$ tones are susceptible to it, H-Deletion can neither possibly jump over nor delete the final $\mathrm{L}$ tone to delete succeeding leftward $\mathrm{H}$ tones. Secondly, assuming the succeeding leftward $\mathrm{H}$ tones could be deleted, in the sense OCP a final $\mathrm{L}$ will constitute a sequence of identical tones with the default $\mathrm{L}$ spreading towards it. Thus, in $(19 \mathrm{~d} \& \mathrm{e}), \mathrm{H}$-Deletion is pre-empted for tonal well-formedness in the resulting phrasal word. A forced application of H-Deletion on N1 in this case will only result in ill-formedness, as shown in (20), a tonal alteration of (19).

(20) H-Deletion and tonal ill-formedness
a. lórì, èkwái
'lorry, a way'
» *lòrikwáí 'a street'
b. ádàsà, m̀má
'mankind, children'
» *àdàsàmòmá 'mankind'
c. táyà, àkóré
'catapult, a branch'
» *tàyà kóré '... for catapult'
d. kòóbì, ǹkwái
'salted-fish, soup'
» *kòòbìǹkwáí 'fish soup'
e. òwúrà, kwà:kú 'lord, $\mathrm{PN}^{\prime}$
» *òwùrà(kwà:)kú 'a PN'

We need to point out that, unlike in N-N phrasal words, Word-Edge does not condition $\mathrm{H}-$ Deletion in N-Adj phrasal word constructions. Thus, in N-Adj phrasal words all that $\mathrm{H}$ Deletion looks for to apply is its prosodic domain, $\phi$. Once the noun and the adjective are phrased together, H-Deletion applies. The irrelevance of Word-Edge in N-Adj phrasal words may be due to the fact that they have an independent set of rules. This position is supported by the additional rule of H-Insertion. Alternatively, we can assume that H-Deletion is copied and blindly applied in N-Adj phrasal words. In (21), we observe the realization of H-Deletion on N1s regardless of Word-Edge failure.

(21) Irrelevance of Word-Edge

$\begin{array}{llll}\text { lórì, kétéwá } & \text { 'lorry, small' } & \text { »lòri kétéwá } & \text { 'a small car' } \\ \text { òwúrà, pápá } & \text { 'lord, good' } & \text { » òwùrà pá(pá) } & \text { 'a good master' }\end{array}$

\footnotetext{
${ }^{11}$ We are not focusing on the difference between an $\phi$ and a clitic group $(C)$, which immediately falls below the $\phi$, at this point. Otherwise, the immediately lower units would have been $C \mathrm{~s}$, not $\omega$ s.
} 


$\begin{array}{llll}\text { táyà, ké!séé } & \text { 'catapult, big' } & \text { » tàyà ké!séé } & \text { 'a big catapult' } \\ \text { dúkù, téńtéń } & \text { 'scarf, long' } & \text { » dùkù téńtéń } & \text { 'a long scarf' } \\ \text { bótó, fó!fóró } & \text { 'a sack, new' } & \text { » bòtò fó!fóró } & \text { 'a new sack' }\end{array}$

\subsection{Exceptions to H-Deletion and Prosodic substance}

From our discussions in section 3.1, one would expect that whenever the Word-Edge condition is met on $\mathrm{N} 1 \mathrm{H}$-Deletion should take place, but this is not the case. As a characteristic of many phonological rules, there are a few N-N phrasal words within which $\mathrm{H}$ Deletion does not apply on N1s, although they satisfy Word-Edge. Some of these phrasal words are exemplified in (22). In the interim, let us refer to these phrasal words as exceptional cases to H-Deletion.

(22) Exceptions to H-Deletion

\begin{tabular}{|c|c|c|}
\hline àkókó, òníní & 'chicken, male' & » àkókóníní 'cockerel' \\
\hline غ̀kóń, غ̇pó & 'the neck, knot' & » èkómṕpó 'goiter' \\
\hline غ̇/ǹsóró, ǹmá & 'heavens, seeds' & » è/ǹsórómmmá 'star(s)' \\
\hline ètí, ǹwíí & 'the head, hair' & » ètíń!wíí 'hair' \\
\hline yàréé, m̀̀á & 'sickness, a bed' & » yàrémú!pá 'sick bed' \\
\hline àsóré, èdáí & 'worship, building' & » àsóré!dáí 'church' \\
\hline
\end{tabular}

Based on the data in (22), we now highlight why our post-lexical rules (particularly, HDeletion) are better analyzed within the prosodic structure. With syntactic analysis, the phrasal words in (22) would just have to be regarded as exceptions to H-Deletion because each N1 meets the Word-Edge condition. Again, N1 and N2 still constitute a common syntactic category of NP, just like those within which H-Deletion consistently applies. Indeed, exceptional classification would be the only option in the syntax. However, with the prosodic account we can conveniently explain that these phrasal words are not exceptions at all, but rather a case of non-attainment of the desired prosodic domain for H-Deletion to apply. We explain this position as follows:

Like Yoruba, Bambara, etc. (Pulleyblank 1986), Akan assigns tones at the lexical level to syllables. Since tone is not generally assigned post-lexically to infer or explain accentual structures, as in a language like Kimatuumbi (Odden 1987), we assume that at the lexical level an assigned tone or tonal structure is also inherently accentuated or given some emphasis/prominence, hence tonal prominence. However, we do not expect to maintain this tonal prominence in a post-lexical environment or construction like the N-N phrasal word, if a particular rule has to apply on it. In phrasal word constructions, therefore, once N1 meets the Word-Edge condition its lexical/basic tonal structure must yield to H-Deletion.

We realize that this is not the case in (22). I suggest that the failure of these N1s to allow HDeletion is due to the manifestation and maintenance of the (inherent) lexical tonal prominence in a post-lexical environment as well. As point (b (i)) of our $\phi$ scheme in (16) underlines, the tonal structures of N1s in (22) defy the application of H-Deletion because each $\mathrm{N} 1$ had primarily phrased separately by the mandate of tonal prominence before rephrasing 
with $\mathrm{N} 2$, that is $\phi$-rephrasing (see (23) below). With $\phi$-rephrasing, the strict prosodic domain requirement of $\mathrm{H}$-Deletion is undermined, and so $\mathrm{H}$-Deletion fails to apply in $\mathrm{N} 1 \mathrm{~s}$. Recall that the required domain of H-Deletion is a primary $\phi$ of two $\omega s$.

Exploring the idea of tonal prominence and its maintenance further, we explain that it follows from the Tonal Prominence scale (de Lacy 2002: 3). ${ }^{12}$ Designated as PROM, this tonal prominence is realized when a 'Word-Edge respected' tone structure of an N1 is maintained in a phrasal word owing to true pronunciation (or phonetic representation) of N1 in the resulting phrasal word. We can, therefore, say that PROM is pragmatically and phonetically underlined and explains the non-submission of 'Word-Edge respected' N1s to H-Deletion. This goes to explain the fact that the non-application of H-Deletion in N1s in (22) is not an exception. Rather, it is an establishment of PROM on N1s that forces them to primarily phrase separately. As shown in (23a), the primary phrasing of N1 institutes a right-edge $\phi$-boundary between it and N2. Considering that the fact that H-Deletion applies within a primary $\phi$ of two _s (and not over a $\phi$-boundary or boundaries) this internal boundary renders H-Deletion inoperative.

a.

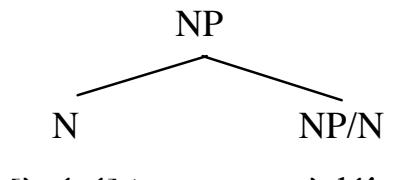

b. $\quad[[\mathrm{N} 1] \phi \mathrm{N} 2] \phi$

Let us note that the establishment of PROM on N1 does not necessarily block the formation of the phrasal word as well. This is because, as also structured in (23b), the 'PROM induced' primary $\phi$ of $\mathrm{N} 1$ further rephrases into one $\phi$ with $\mathrm{N} 2$, thereby finally resulting in phrasal word domain (i.e. N1 and N2 in one $\phi$ ). The primary separate phrasing of N1, therefore, only results in domain recursion of one $\phi$ within another $\phi .{ }^{13}$ As exemplified in (24) below, a restructuring of (22), the recursive structure also results on the account that the complement, $\mathrm{N} 2$, cannot constitute a separate $\phi$ on its own and has to be mapped into a common $\phi$ with the prominent head, N1.

(24) Non-application to H-Deletion
a. [[àkókó] $\phi$ òníní] $\phi$ 'chicken, male'
» àkókóníní 'cockerel'
b. [[غ̀kóń] $\phi$ غ̀pó] $\phi$ 'the neck, knot'
» èkómpó 'goiter'
c. [[ǹsóró] $\phi$ m̀̀má $] \phi$ 'heavens, seeds'
» ǹsórómmá 'star(s)'
d. [[ètíê] $\phi$ ǹwíi $] \phi$ 'the head, hair'
» ètíń!wíí 'hair'
e. [[yàréć] $\phi$ m̀̀á] $\phi$ 'sickness, a bed'
» yàréḿ!pá 'sick bed'
f. [[àsóré] $\phi$ èdáí] $\phi \quad$ 'worship, building'
» àsóré!dáí 'church'

\footnotetext{
${ }^{12}$ The Tonal Prominence scale proposes that higher tone is more prominent than lower tone. In the case of Akan, a two-tone language, it follows that an $\mathrm{H}$ tone is prominent than an $\mathrm{L}$ one (i.e. $H>L$ ). Thus, the superiority or prominence of an $\mathrm{H}$ tone over an (default) $\mathrm{L}$ takeover is also emphasized post-lexically if it fails to submit to a dominant rule, here H-Deletion.

${ }^{13}$ I am inspired by Inkelas Zec \& Inkelas (1990), etc. proposition of a phonological word subcategorization frame in the structuring of this domain recursion. That is, the recursion could be interpreted as a subcategorization frame for a $\phi$ of a single lexical syntactic unit.
} 
With the $\phi$ recursive structure, both the phrasal word construction and lack of H-Deletion in (24) are adequately accounted for with a common prosodic domain of rule analysis.

Observe also in (23) that, Prefix deletion and DiphSimple also adopt the $\phi$ as their domain of operation, although they are not restricted to apply in a primary $\phi$, as does H-Deletion. Accordingly, both Prefix deletion and DiphSimple apply over a $\phi$-boundary as long as this boundary is internal to another $\phi$, hence the realization of Prefix deletion in (24a, b \& f) and DiphSimple at word boundary in ( $24 \mathrm{~d} \& \mathrm{e})$. It will become evident in section 4 , however, that where constituents in an NP (i.e. N-N or N-Adj sequence) individually phrase into separate $\phi s$, in which case there is also a left boundary to the complement (i.e. N2 or Adj), they cannot rephrase into a common $\phi$. In this wise, a phrasal word does not result and neither Prefix deletion nor DiphSimple also apply.

\subsection{Rephrasing and Boundary Assimilation rule}

Following the $\phi$-rephrasing structure in (23b) and its manifestation in the phrasing of the phrasal words in (24), a tone sandhi also sets off. To be precise, the internal $\phi$-boundary that characterizes the domain of these phrasal words sensitizes this tone sandhi, which we refer to as the boundary assimilation rule (hereafter, B-A). Although B-A is particularly triggered by the final $\mathrm{H}$ tone of the head and realized at the left-edge of a single-segment prefixed complement in its application, domain-wise, the rule applies if there is $\phi$-boundary or boundaries between N1 and N2. ${ }^{14}$ As could be observed in (25) below, a reanalysis of (24), this means that B-A cannot apply without the internal $\phi$-boundary that defines the primary $\phi$ domain of N1. Stated in (26), therefore, it is obvious that B-A is a $\phi$-domain juncture rule. ${ }^{15}$

(25) Tone sandhi: Boundary Assimilation
a. [[àkókó] òníní] $\phi$ » [[àkókb́] $\phi$ óníní] $\phi$
» àkókóníní 'cockerel'

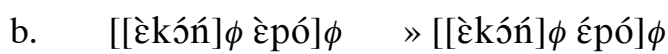
» દ̀kómpó 'goiter'
c. [[ǹsóró $] \phi$ m̀̀má $] \phi ~ »[[$ ǹsóró $] \phi$ ḿmá $] \phi$
» ǹsórómmá 'star(s)'
d. [[ètí] $\phi$ ǹwíi $] \phi \quad »[[$ ètíré $\phi \phi$ ń!wíi $] \phi$
» ètíń!wîí 'hair'
e. [[yàréé] $\phi$ m̀̀á $] \phi ~ »[[y a ̀ r e ́ \varepsilon ́] \phi$ ḿ! pá $] \phi$
» yàréḿ!pá 'sick bed'

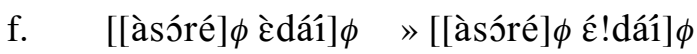
» àsóré!dáí 'church'

(26) Boundary Assimilation rule

a. $\quad\left[P f x \grave{\sigma}^{-}\right]_{\omega} \rightarrow[P f x \text { ó- }]_{\omega} /\left[\left[_{\mathrm{N}_{1}} \ldots \sigma^{-}\right]_{\phi} \_\right]_{\phi}$

Since in a phrasal word construction a vowel prefix in N2 is deleted (recall the prefix deletion rule), the effect of $\mathrm{B}-\mathrm{A}$ is not obvious if the tone of the prefix is deleted as well. That is, with B-A, assimilating N2 prefix is expressed either through deletion or dislodging, hence

\footnotetext{
14 Whether there will be a $\phi$-boundary or boundaries between the two syntactic units depends on the prosodic status of the complement, as an $\phi$ or a $\omega$. There will be left and right $\phi$-boundaries between the two syntactic units if the complement is also $\phi$ (see section 4 ) and only a right $\phi$-boundary between them if the complement is only a $\omega$, as in $(24 / 25)$.

${ }^{15}$ See Selkirk (1980); Nespor/Vogel (1986); Rice (1990); etc. for discussions on domain-sensitive rules, i.e. domain span, domain limit and domain juncture rules.
} 
assimilation-by-deletion and assimilation-by-dislodging respectively. With assimilation-bydeletion, the 'assimilator' $H$ just deletes the lexical $L$ tone of an absorbing prefix, as in the non-downstep cases in (25a-c). In contrast, with assimilation-by-dislodging, the lexical L tone of an absorbing prefix is only dislodged by the 'assimilator' $\mathrm{H}$. As also shown in the cases in (25d-f), the dislodged $\mathrm{L}$ tone then causes downstepping in the following $\mathrm{H}$ tone in the stem. With prosodic analysis, therefore, explanation to tonal alterations in N2 is also made possible and clear.

\section{$4 \quad$ Phrasal words and the morphophonemic property of number}

Number is regularly represented by a prefix in the noun in Akan (Osam 1993; Bodomo and Marfo 2002). ${ }^{16}$ Almost all Akan nouns are underlyingly prefixed in their singular forms. For this reason, let us consider the singular form of the noun as the default or unmarked case, with which there has not been any mutation. We also consider the plural as the marked case where number is always marked in the prefix by either the vowel $\backslash a-\backslash$ or a syllabic nasal $/ \mathrm{N} /$, homorganic to the stem-initial consonant. In the following, we focus on the marked cases, with which number (i.e. plurality) is made distinct. Based on their mass or uncountable identity, let us also note that nouns with underlying syllabic nasal prefix (e.g. ǹsúó 'water or river' etc.) are conceptually classed as plural forms. In this paper, however, we still consider them as default forms with the regular singular noun forms.

\subsection{Number, rules application and phonological phrasing}

In the following, we discuss the contribution of plurality in $\mathrm{N}-\mathrm{N}$ and $\mathrm{N}$-Adj word orders to phrasal word constructions, and how it relates to the composition of the $\phi$-domain. In N-N word order, number is sometimes represented in both constituents for an optional agreement in number or only in $\mathrm{N} 1$ just for plurality of the construction. Conversely, number must be represented in both constituents for grammaticality in $\mathrm{N}$-Adj case. ${ }^{17}$ When number is represented in the complement (i.e. N2 or Adjective) a phrasal word is not obtained. Following that, the essential rules we have observed - i.e. H-Deletion, Prefix deletion and DiphSimple - also fail to apply in both cases of N-N and N-Adj. Let us observe these facts in $\mathrm{N}-\mathrm{N}$ ordering in (27).

\footnotetext{
${ }^{16}$ Number marking is done by either a vowel or a syllabic nasal. A few other nouns do not have or are not said with a prefix, e.g. boto 'sack', but they are prefixed in their plural forms, that is mmoto (< mboto ) or aboto 'sacks'. Others also have prefixes in their singular forms, which are simply unchangeable in the plural. These are the uncountable nouns; e.g. ìkwán 'soup', etc.

${ }^{17}$ Let us note that number representation in an adjective is indeed nominalization of the adjective. Nominalization of adjectives is also one of the ways of increasing the stock of nouns in Akan. With number in the adjective, the adjective has actually become a noun through a class changing derivation.
} 
(27) Number representation in N2

\begin{tabular}{|c|c|c|c|}
\hline a. & $\begin{array}{l}\text { ǹyàmé, ǹ-sćḿ } \\
\text { ǹyàmé ń!sćmú }\end{array}$ & $\begin{array}{l}\text { 'a god, stories' } \\
\text { 'issues about God' }\end{array}$ & not *ǹyàmè ǹséḿ \\
\hline b. & $\begin{array}{l}\text { sàkúó, ǹ-nwóm } \\
\text { sàkúó ń!nwóḿ }\end{array}$ & $\begin{array}{l}\text { 'piano, songs' } \\
\text { 'music from piano' }\end{array}$ & not *sàkùò ǹnwóm \\
\hline c. & ǹnùá, à-dáí & 'woods, houses' & \\
\hline$»$ & ǹnùá á!dáí & 'a wooden houses' & not *ǹnùà àdáí \\
\hline d. & dwóń!só, à-dáí & 'urine, houses' & \\
\hline$»$ & dwóń!só á!dáí & 'urinal places' & not *dwòǹsò àdáí \\
\hline e. & $\begin{array}{l}\text { dàdéé, à-ś́í } \\
\text { dàdéć á!sćí }\end{array}$ & $\begin{array}{l}\text { 'steel, bowls' } \\
\text { 'bowls of steel' }\end{array}$ & not *dàdèc̀ àsćí \\
\hline
\end{tabular}

We have noted that a N-N/N-Adj phrasal word is obtained when the two syntactic words could constitute one $\phi$. Phrasal words are not obtained in (27) because, this time, the constituents in the NP cannot also be mapped into a common $\phi$. As shown in (28) for N-N and N-Adj orderings, the syntactic words in the NP had constituted separate phrases.

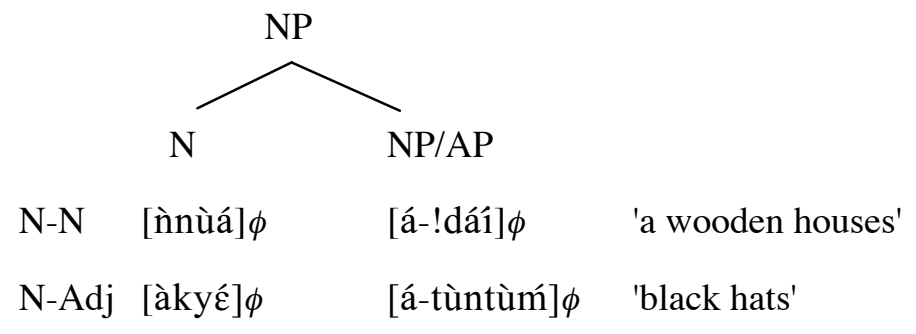

Explaining further and as predicted by point (b (ii)) of our $\phi$ algorithm in (16), that is a pluralized complement phrases separately, the plural marker in the complement, as a marked phonemic unit, renders the complement morphophonemically complex to be phrased together with the head. Again, unlike the head, a complement does not institute a $\phi$ subcategorization frame to rephrase with its head. We assume here that a subcategorization frame should be rightward directed, ${ }^{18}$ as in (23b), and as such a property of the head. When the complement primarily phrase separately, therefore, the head has to phrase alone as well.

Following the failure of NP to map into one $\phi$, the exclusive domains of H-Deletion, Prefix deletion and DiphSimple are not attained, hence the non-application of these rules in (27). We have noted that $\mathrm{H}$-Deletion only applies within a primary $\phi$ of two $\omega \mathrm{s}$. We also noted that, although not always in a primary $\phi$, Prefix deletion and DiphSimple apply only if the constituents involved are finally phrased together into one $\phi$. In the sense of prosodic analysis, therefore, it follows theoretically that the rules cease to apply when N2 or Adj becomes morphophonemically complex with plurality and phrases separately. As also exemplified with

\footnotetext{
${ }^{18}$ By the term, rightward directed, we mean that prosodic subcategorization should be initiated from the head, as the left-aligned constituent. Hence, a subcategorization frame should be in the order of $\phi$ of a head rephrasing with its complement (i.e. 'head $l \rightarrow$ complement2') not $\phi$ of a complement rephrasing with its head (i.e. 'head2 $\leftarrow$ complement $\left.1^{\prime}\right)$.
} 
$\mathrm{N}$-Adj cases in (29), with regards to H-Deletion, the starred cases are not testified if not totally ungrammatical.

(29) $[N 1] \phi[A d j] \phi$ : Number representation in Adj

a. à-kyé, à-tùntùm 'hats, black ones'

» àkyé átùntùm 'black hats' not *àkyè àtùntùm

b. à-séí, à-kèséé 'bowls, big ones'

» àsći ákèséć 'big bowls' not *àsèi àkèséć

c. ̀̀-tóá, ǹ-kétéwá 'knives, small ones'

» ǹtóá ń!kétéwá 'small knives' not *ǹtòà ǹkétéwá

d. ǹtòmá, àfítáá 'clothes, white ones'

» ǹtòmá á!fítáá 'white clothes' not *ǹtòmà àfitáá

We realize in (29) that $\mathrm{H}$-Insertion, which applies in N-Adj sequences, also fails to apply on the adjectives. This explains the fact that, as a domain-limit rule, H-Insertion needs the absorbing syllable, the stem-initial of the adjective, to absolutely align to the left-edge of $\omega / \phi$ domain of occurrence. Explicitly, as we can observe in (29), in a 'pluralized' adjective the number/plural prefix constitutes an extra syllable in the adjective, which then occupies the immediate left of the occurring $\phi$-domain, rather than the stem-initial syllable of the adjective. In so doing, the prefix foils the stem-initial syllable left-edge sensitivity of H-Insertion. HInsertion is thereby rendered inappropriate.

What is left to account for in (27) and (29) is B-A. We have observed that B-A, a domain juncture rule, is triggered on the realization of $\phi$-boundary or boundaries between constituents. Based on the attainment of the boundaries, B-A consistently applies. Its application results in the tonal alterations we see on N2s and Adjs in (27) and (29) respectively.

\section{Conclusion}

We have shown that in the phonology-syntax connection the hierarchically fashioned domains in the prosodic structure provide the desirable platform for a better and holistic explanation of post-lexical phonological processes. We have noted the importance of the syntactic constituent structure, but we have also realized that it is inadequate in the provision of the necessary domains of rule application. In line with the indirect reference hypothesis, therefore, we advance the suggestion that, with other grammatical resources, the syntactic structure is employed as an input for the definition of the prosodic domains. This suggestion also establishes that the syntactic domains cannot always be isomorphic to the prosodic domains. Otherwise, there would not have been any need for the prosodic structure.

With prosodic phonological manipulations, we have established where and when a particular rule among those we have discussed should apply. We have noted that H-Deletion, Prefix deletion and Diphthong simplification are $\phi$-internal rules. H-Insertion is also only sensitive to a stem-initial syllable that immediately aligns to the left-edge of a succeeding $\omega / \phi$-domain 
while Boundary assimilation (B-A) applies over $\phi$-boundaries. Having been able to adequately explain the formation or otherwise of $\mathrm{N}-\mathrm{N}$ and $\mathrm{N}$-Adj phrasal words and the application of associated phonological rules touched on in this paper, I suggest that it is evidently crucial to explain post-lexical phonological phenomena within the confines of prosodic phonology.

\section{References}

Anderson, Stephen R. (1985): "Typological distinction in word formation". In: Shopen, Timothy (ed.): Language Typology and Syntactic description. Vol. 3. Cambridge etc.: 356.

Anttila, Arto/Bodomo, Adams (2000): "Tonal polarity in Dagaare". In: Carstens, Vicki and Parkinson, Frederick (eds.): Trends in African Linguistics 4: Advance in African Linguistics. Trenton, NJ: 119-134.

Bodomo, Adams B./Marfo, Charles O. (2002): The Morphophonology of Noun Classes in Dagaare and Akan. Paper presented at the 33rd. Annual Conference on African Linguistics (ACAL 33). U.S.A.: Ohio University, Athens. March 2002.

de Lacy, Paul (2002): "The interaction of tone and stress in Optimality Theory". Phonology 19: 1-32.

Dolphyne, Florence Abena (1988): The Akan (Twi-Fante) Language: Its Sound systems and tonal structure. Accra.

Frascarelli, Mara (2000): The Syntax-Phonology Interface in focus and topic constructions in Italian. Dortrecht. (= Studies in Natural Linguistic Theory, Volume 50).

Goldsmith John (1976): Autosegmental phonology. Cambridge, Mass.: MIT Ph.D. dissertation. Distributed by Indiana University Linguistics Club.

Hayes, Bruce (1989): "The prosodic hierarchy in meter". In: Kiparsky, P./Youmans, G. (eds.): Rhythm and Meter. San Diego: 201-260.

Inkelas, Sharon (1989): Prosodic Constituency in the Lexicon. PhD thesis, Stanford University.

Kaisse, Ellen M. (1985): Connected Speech: The Interaction of Syntax and Phonology. Orlando.

Kiparsky, Paul (1985): "Some consequences of lexical phonology". Phonology Yearbook 2: 85-138.

Leben, William (1973): Suprasegmental Phonology. New York.

Lieber, Rochelle (1980): On the organisation of the Lexicon. Ph.D. dissertation, M.I.T.

Marfo, Charles O. (2001): Some NP and VP-internal tonology of Akan: An autosegmental account. An unpublished MPhil thesis. The University of Tromsø, Norway.

Mohanan, Karuvannur Puthanveet (1986): The Theory of Lexical Phonology. Dordrecht.

Nespor, Marina/Vogel, Irene (1982): "Prosodic domains of external sandhi rules". In: van der Hulst, H./Smith, N. (eds.): The Structure of Phonological Representations (Part I). Dordrecht: 225-255.

Nespor, Maria/Vogel, Irene (1986): Prosodic Phonology. Dordrecht. 
Odden, David (1986): "On the role of obligatory contour principle in phonological theory". Language 62: 353-383.

Odden, David (1987): "Kimatuumbi phrasal phonology". Phonology Yearbook 4: 13-26.

Osam, Emmanuel Kweku A. (1993): "The Loss of the Noun Class System in Akan". Acta linguistica hafniensia vol. 26. Linguistics Circle of Copenhagen: 81-106.

Pulleyblank, Douglas George (1986): Tone in Lexical Phonology. Dordrecht.

Rice, Keren D. (1990): "Predicting Rule Domains in the Phrasal Phonology". In: Inkelas, Sharon/Zec, Draga (eds.): The phonology-syntax connection. Chicago: 289-312.

Seidl, Amanda (2001): Minimal indirect reference: a theory of the syntax-phonology interface. New York.

Selkirk, Elisabeth O. (1980): "Prosodic domains in phonology: Sanskrit revisited". In: Aronoff, M./Kean M.-L. (eds.): Juncture. Saratoga, Calif.: 107-129.

Selkirk, Elisabeth O. (1981): "On the Prosodic Structure and its Relation to Syntactic Structure". In: Fretheim, T. (ed.): Nordic Prosody II. Trondheim: 11-40.

Selkirk, Elisabeth O. (1982): The syntax of words. Cambridge, MA.

Selkirk, Elisabeth O. (1984): Phonology and Syntax: The Relation between Sound and Structure. Cambridge, MA.

Selkirk, Elisabeth O. (1986): "On derived domains in sentence phonology". Phonology Yearbook 3: 371-405.

Vogel, Irene (1984): "On constraining prosodic rules". In: van der Hulst, H./Smith, N. (eds.): Advances in Nonlinear Phonology. Dordrecht: 217-233.

Truckenbrodt, Hubert (1999): "On the Relation between Syntactic Phrases and Phonological Phrases". Linguistics Inquiry 30: 219-255.

Zec, Draga/Inkelas, Sharon (1990): "Prosodically Constrained Syntax". In: Inkelas, Sharon/Zec, Draga (eds.): The Phonology-Syntax Connection. Chicago: 365-378. 